\title{
RESUME HUKUM TATA NEGARA
}

Nama: Muhammad Ikhsan Azhari

Nim: 10200120235

Materi 1

- $\quad$ Pengertian hukum tata negara menurut van der pot

Hukum tata negara adalah peraturan-peraturan yang menentukan badan-badan yang di perlukan beserta kewenangannya masing-masing hubungannya satu sama lain,serta hubungannya dengan individu warga negara dalam kegiatannya.

- $\quad$ Pengertian hukum tata negara menurut paul scholten

Hukum tata negara adalah het recht dat regelt destaatsorgani satie, atau hukum yang mengatur mengenai tata organisasi negara

- $\quad$ Pengertian hukum negara menurut christian van vollenhoven

Hukum tata negara mengatur semua masyarakat hukum atasan dan masyarakat hukum bawahan menurut tingkatannya,dan dari masing-masing itu menentukan wilayah lingkungan masyarakatnya,badan-badan yang berkuasa,fungsi,susunan dan wewenang masing-masing dalam lingkungan masyarakat hukum tersebut

- $\quad$ Pengertian hukum tata negara menurut J.H.A logemann

Hukum tata negara adalah hukum yang mengatur mengenai

Materi 2

- Sumber hukum tata negara

Sumber hukum tata negara yang diakui secara umum adalah:

1. undang-undang dasar dan peraturan perundang-undangamtertulis baik UUD maupun peraturan perundang-undangan merupakan produk leguslasi oleh lembaga yang mendapatkan delegasi kewenangan regulasi,sehingga bentuknya bisa legislative acts seperti undang-undang maupun excutive acts seperti peraturan pemerintah.

2. Yurisprudensi putusan pengadilan

3. Konvensi ketatanegaraan- kebiasaan,kelaziman,dan prektik yang baik yang di lakukan dalam penyelenggaraan negara meskipun tidak didasarkan pada aturan tertulis

4. Hukum internasional-traktat atau perjanjian antar negara

5. Doktrin ilmu hukum tata negara- pendapat ilmuan yang kredibel dan mendapatkan pengakuan

- Sumber hukum tata negara indonesia

Secara umum,hukum tata negara positif dalam hal ini sumber hukum indonesia tidak jauh berbeda dengan sumber hukum tata negara umum,dan umumnya para ahli tetap membagi sumber hukum tata negara indonesia menjadi sumber hukum formil dan materil 
Salah satu sumber hukum materil menurut jimly assihiddiqie,sumber hukum materil hukum tata negara indonesia adalah pancasila,dimana rumusan sila-sila pancasila merupakan falsafah hidup bernegara dan pandangan hidup bangsa,pancasila merupakan sumber hukum materil yang tidak hanya sebatas menjiwai,tetapi harus dilaksanakan dan tercermin dalam setiap peraturan hukum di indonesia

Sumber hukum formil menurut jimly assihiddiqie,sumber hukum formil hukum tat negara indonesia adalah undang-undang dasar NRI 1945,peraturan perundangundangan,yurisprudensi,konvensi ketatanegaraan,dan traktat,dan doktrin

\section{Materi 3}

\section{- $\quad$ Asas-asas hukum tata negara}

Pengertian asas hukum

Pengertian asas hukum menurut H.J.Homes asas hukum tidak boleh dianggap sebagai normanorma hukum yang konkret,tetapi perlu di pandang sebagai dasar-dasar umum atau petunjuk-petunjuk bagi hukum yang berlaku

- $\quad$ Fungsi asas hukum

Fungsi asas hukum sebagai penjaga konsistensi

Salah satu fungsi dari asas hukum adalah menjaga ketaatan atau konsistensi.asas hukum akan berfungsi untuk menjaga agar dalam proses pembentukan peraturan hukum,maupun dalam penerapannya tetapi mengacu pada ketentuan yang berlaku inilah yang mendasari Kenapa setiap penyelenggaraan negara wajib memahami asas-asas hukum Dengan memahami asas hukum diharapkan dapat meminimalisir penyelenggaraan.

- $\quad$ Fungsi asas hukum untuk mengatasi konflik

Asas hukum untuk mengatasi konflik bahwa asas hukum dapat dijadikan sebagai salah satu batu uji jika terjadi pertentangan antara peraturan hukum ataupun antar organ atau lembaga negara.sebab, tidak dapat di pungkiri bahwa kerap kali kita menemukan adanya benturan antar peraturan atau tindakan Pemerintahan yang satu dengan yang lainnya. dalam kondisi demikian, asas hukum dapat difungsikan sebagai instrumen untuk mengatasi konflik.

\section{- Asas pancasila}

Asas Pancasila merupakan sumber dari segala sumber hukum dalam bernegara, maka seluruh proses penyelenggaraan negara harus sesuai dan berdasarkan nilai-nilai Pancasila, termasuk demos isikan atau menempatkan Pancasila sebagai asas hukum tata negara.

Nilai-nilai Pancasila yang dijadikan asas dalam bernegara telah terejawantahkan melalui empat pokok-pokok pikiran dalam pembentukan UUD NRI 1945 yaitu, pertama,

" melindungi segenap bangsa Indonesia dan seluruh tumpah darah Indonesia dengan berdasar atas persatuan dengan mewujudkan keadilan sosial bagi seluruh rakyat Indonesia.

"kedua, " negara hendak mewujudkan keadilan sosial bagi seluruh rakyat" ketiga,"negara yang berkedaulatan rakyat,berdasarkan atas kerakyatan dan permusyawaratan perwakilan.

Keempat, " negara berdasar atas Ketuhanan Yang Maha Esa menurut dasar kemanusiaan yang adil dan beradab" 
- $\quad$ Asas negara hukum

Istilah negara hukum merupakan terjemahan dari rechsstaat (eropa kontinental) dan the rule of law anglo saxon cenderung judical.

Penegasan Indonesia sebagai negara hukum dapat dijumpai pada pasal 1 ayat 3 undangundang Dasar Negara Republik Indonesia tahun 1945 “Negara Indonesia adalah negara hukum".

- Asas kedaulatan rakyat dan demokrasi

Pasal 1 ayat 2 undang-undang Dasar Negara Republik Indonesia tahun 1945 “ Kedaulatan berada ditangan rakyat dan dilaksanakan menurut undang-undang dasar”

Rumusan pasal 1 ayat 2 tersebut meneguhkan konsep kekuasaan tertinggi dalam bernegara adalah kehendak rakyat dan dilaksanakan dengan mekanisme kenegaraan berdasarkan konstitusi. Rumusan tersebut berbeda dengan rumusan pasal sebelumnya dilakukan Amandemen UUD dimana kedaulatan rakyat dijalankan sepenuhnya oleh Majelis Permusyawaratan Rakyat.

- $\quad$ Asas pemisahan kekuasaan dalam check balances

Amandemen UUD 1945 sebagai buah dari reformasi 1908 dalam membawa perubahan mendasar pada kehidupan bernegara dan berbangsa. Salah satunya adalah munculnya kesadaran kolektif untuk melakukan perubahan struktur kelembagaan negara, pengesahan kewenangan, perimbangan kekuasaan, penguatan sistem presidensil, perubahan sistem pemilihan presiden dan wakil presiden, dan pembentukan lembaga negara baru, yang kesemuanya bertujuan untuk memperkuat penerapan prinsip saling mengimbangi dan saling kontrol (check and balance) kantor cabang cabang kekuasaan (legislatif,eksekutif,dan yudikatif) yang selama masa orde baru tidak berjalan efektif, bahkan cenderung terjadi monopolistik kekuasaan pada cabang kekuasaan eksekutif.

\section{Materi 4}

Sejarah ketatanegaraan indonesia

Sejarah ketatanegaraan Indonesia dapat di telusuri antara lain berdasarkan perubahan Konstitusi, bentuk negara, bentuk Pemerintahan, sistem pemerintahan, dan lainnya.

\section{- $\quad$ Konstitusi}

Konstitusi adalah hukum dasar yang dijadikan acuan atau pedoman dalam suatu negara. Sebagai hukum dasar, konstitusi dapat berbentuk hukum dasar yang tertulis dan dapat pula tidak tertulis. Indonesia menganut konstitusi tertulis yang disebut dengan undang-undang dasar. Sejarah ketatanegaraan Indonesia telah beberapa kali mengalami pergantian, dimulai dari UUD 1945 konstitusi RIS, UUD sementara, dan akhirnya kembali ke UUD 1945, lalu kemudian mengalami perubahan pada tahun 1999, 2000, 2001, dan tahun 2002.

\section{- UUD Sementara}

Diterimanya hasil KMB dengan konsekuensi perubahan konstitusi dan bentuk negara, menurut beberapa kalangan dianggap sebagai strategi dan taktik para tokoh tokoh bangsa untuk menyiasati agar keinginan Belanda untuk kembali menjajah Indonesia tidak merepotkan bangsa Indonesia. 
Materi 5

Konstitusi sebagai objek kajian hukum tata negara

- $\quad$ Istilah konstitusi

Istilah konstitusi terdapat beberapa istilah yang memiliki arti yang sama dengan konstitusi, seperti constitutie dan grandwet (belanda), constitutio (latin dan inggris), fendamental laws (amerika serikat),dan di indonesia digunakan istilah Undang-undang dasar yang merupakan terjemahan dari bahasa belanda Grondwet.

- $\quad$ Pengertian konstitusi

Menurut C.F.Strong

kumpulan prinsip-prinsip yang mengatur kekuasaan pemerintahan hak-hak pihak yang diperintah ( rakyat ), dan hubungan di antara keduanya, baik yang bentuknya terdokumentasi maupun tidak terdokumentasi

Menurut James Bryce

" suatu kerangka masyarakat politik (negara) yang diorganisir dengan dan melalui hukum;

hukum menetapkan adanya lembaga-lembaga permanen dengan fungsi yang telah diakui dan hak-hak yang telah ditetapkan.

Menurut Jimly Assahiddiqie

“ hukum dasar yang dijadikan pegangan dalam penyelenggaraan suatu negara titik konstitusi dapat berupa hukum dasar tertulis yang lazim disebut undang-undang dasar dan dapat pula tidak tertulis"

Menurut Brian Thompson

a contitution is a document which contains the rule for the operation of an organization.

Konstitusi dalam pengertian sempit adalah konstitusi yang terdokumentasi atau tertulis (loi constitunelle), yang berisi ketentuan-ketentuan atau peraturan-peraturan dengan Dasar atau hukum dasar ( piagam,treaty, dan undang-undang dasar).

Konstitusi dalam pengertian luas adalah keseluruhan dari ketentuan-ketentuan atau peraturan-peraturan Dasar atau hukum dasar ( droit constitunelle), baik yang tertulis maupun yang tidak tertulis.

- $\quad$ Fungsi dan tujuan konstitusi

1. Sebagai sumber hukum

2. Sebagai penentu, pembagi, dan pembatas kekuasaan organ negara.

3. Sebagai pemberi atau penyalur atau pengalih kewenangan kepada organ negara.

4. Sebagai pengatur hubungan antar organ negara 


\section{Nilai konstitusi}

- Nilai yang bersifat normatif

- Nilai yang bersifat nominal

- Nilai yang bersifat sematik

\section{Tujuan konstitusi}

- $\quad$ konstitusi bertujuan untuk menetapkan pelaksanaan kekuasaan yang berdaulat atau menjadi pedoman penyelenggaraan negara

- Konstitusi bertujuan untuk menjamin hak-hak rakyat

- Konstitusi bertujuan untuk membatasi tindakan sewenang-wenang dan pemerintah

\section{Materi 5}

\section{Organ dan fungsi kekuasaan negara}

Dalam diskursus mengenai organisasi negara, terdapat 2 unsur pokok yang saling berkaitan, yaitu organ dan fungsi.

\section{Fungsi-fungsi kekuasaan}

Negara hukum yang dalam bahasa Belanda dan Jerman disebut rechtsstaat memiliki ciri-ciri, yang salah satunya menekankan Adanya pembagian kekuasaan, sebagaimanaYang dipelopori oleh friedrich julius stahl,yaitu:

1. Pembagian kekuasaan

2. Perlindungan hak asasi manusia

3. Pemerintahan berdasarkan undang-undang

4. peradilan administrasi

\section{Kekuasaan legislatif}

\section{Fungsi leguslatif}

Fungsi legislatif atau pengaturan adalah salah satu fungsi utama dari cabang kekuasaan legislatif, yang berwenang merumuskan atau Membentuk peraturan yang bersifat mengikat dan membatasi terdapat empat bentuk kegiatan yang berkaitan dengan fungsi legislatif yaitu:

- Prakarsa Pembuatan undang-undang

- Pembahasan rancangan undang-undang

- Persetujuan atas pengesahan rancangan undang-undang

- pemberian persetujuan pengikatan atau ratifikasi atas perjanjian atau persetujuan internasional dan dokumen-dokumen hukum yang mengikat lainnya.

Fungsi pengawasan legislatif

Fungsi pengawasan legislatif atau parlemen memiliki fungsi untuk melakukan pengawasan terhadap proses perumusan dan penentuan kebijakan pemerintah, agar tidak sampai bertentangan dengan ketentuan yang berlaku. Secara teoritik fungsi pengawasan dapat berupa

- pengawasan terhadap penentuan kebijakan

- pengawasan terhadap pelaksanaan kebijakan

- pengawasan terhadap penganggaran dan belanja negara 
- pengawasan terhadap pelaksanaan anggaran dan belanja negara

- pengawasan terhadap kinerja pemerintah

- pengawasan terhadap pengangkatan Pejabat publik. 